\title{
Politieke en sosiale vraagstukke in die prediking
}

\author{
TFJ Dreyer
}

\section{Abstract}

Political and social issues in preaching

This paper is an attempt to provide guidelines for preaching with regard to the socio-political aspects of society. The dangers of political preaching as an enigma of contemporary preaching are analysed. Preaching is a complicated process relating to hermeneutics and communication. Obstacles in disturbing this process are pinpointed in the study. The paper's aim is to find ways to overcome the disturbance of the normal hermeneutical process, especially where political aspects are concerned.

\section{TERREINVERKENNING}

De ware actuele prediking laat de kracht van het Woord gelden in het heden, is in 'actu' $\mathrm{d}$ w z werkend, handelend, geldend, zingevend. Ze houdt zich bezig met de problematiek van de huidige tijd, spreekt de taal van de moderne mens, appelleert aan het levensgevoel en denkklimaat van deze eeuw en orienteert zich aan de gesteldheid van de concrete. In deze sfeer laat zij tegenover allerlei fronten de stem van de levende God horen. Deze opdracht veronderstelt telkens een artistieke creatie, een inleven in de tekst, een inleven in de levensproblematiek van de gemeente (Jonker 1973: 43).

Met hierdie opmerking van Jonker dring die probleem van politieke en sosiale vrae in die prediking outomaties die gesigsveld van die prediker binne. Die meeste teoloë is feitlik eenstemmig dat die prediking vanuit sy wese nie anders kan as om ook sosio-politiese probleme aan te sny nie. Ook binne die teologiese dampkring van die drie Afrikaanse susterkerke waarop hierdie studie in besonder afgestem word, word dit aanvaar dat die kerk in sy prediking ' $n$ verantwoordelikheid en gerigtheid het ten opsigte van sosio-politiese vraagstukke. 'Die Bybelse boodskap mag nie in die behandeling van abstrakte godsdienstige sake opgaan nie, maar moet aan konkrete verskynsels en probleme van ons moderne samelewing aandag gee, en gevolglik ook as ' $n$ ter sake bood- 
skap vir die politiek verkondig word' (Gaum 1981: 18). 'Al mag die kerk nie politieke programme uitwerk nie, moet hy tog in die Naam van Christus op onreg en lyding wys wat deur politieke programme veroorsaak word' (Jonker 1976: 124). Oberholzer (1985: 14-28) dui die verskillende terreine aan waar die Hervormde Kerk volgens sy belydenis en kerkorde ' $n$ taak het ten opsigte van die onderhawige probleem. Hy stel onder andere dat die Kerk in sy prediking, kategese en herderlike werk ook die taak het om sy lidmate te lei tot die aanvaarding van hulle medeverantwoordelikheid vir die daarstelling en funksie van die burgerlike owerheid. 'Aan wêreldonttrekking, nie-politiek, kluisenaarsbestaan is vir die kerk nie te dink nie. Dan hou hy op om kerk te wees en verloën hy die heerskappy van God .... Die krag waarmee die kerk sy lidmate vermaan en onderrig, dra by tot die krag van die lidmaat se inset in die politiek en bepaal ook die kwaliteit van die politieke optrede in die staat as geheel' (Oberholzer 1985: 24).

Hieruit blyk voldoende dat politieke en sosiale vrae in die prediking aan die orde sal moet kom. Die knellende vraag is egter hoe dit in die prediking van die kerk verwoord moet word. Indien dit nie nader gekwalifiseer word nie, kan die kerk in sy prediking maklik verstrik raak in ' $n$ eensydige 'politieke prediking' wat in sommige teologiese kringe 'n modewoord geword het. Met die term 'politieke prediking' word nie slegs bedoel die teologiese besigwees met vrae rakende die politieke en sosiaal-etiese verantwoordelikheid van die gelowige nie dit gaan om veel meer! Dit gaan om 'n politieke interpretasie van die evangelie. 'Een betere naam zou dan ook zijn: politieke hermeneutiek. Deze wil een interpretatieperspektief bieden waarin de politiek wordt gezien als de alles omvattende en beslissende ruimte waarbinnen de christelijke praxis waarheid moet worden' (Velema 1972: 9). Die hermeneutiese vertrekpunt van hierdie 'politieke prediking' is ook dikwels gevorm deur 'n Marxistiese siening van die maatskappy. Saam met Velema (1972: 27) wil ons die term 'politieke prediking' afwys. In die term 'politieke prediking' bepaal politiek die wese van die prediking. Runia (1985: 85) sê tereg: 'In veel gemeenten lijden mensen onder een sterk politiek-gerichte prediking. Het is daarbij opvallend dat het bijna altyd een links-politieke prediking is.'

Aan die een kant staan die kerk dus voor die verantwoordelikheid dat die Woord sosio-politiese relevansie het, maar andersyds voor die gevaar om te swig voor die versoeking van 'n eensydig, hermeneutiesgeinspireerde 'politieke prediking'. In die hantering van hierdie vraagstuk kan verskillende metodes en modelle geïdentifiseer word. 


\section{2. 'N VERSKEIDENHEID VAN MODELLE}

In 'n publikasie van die Gereformeerde Ekumeniese Sinode oor die kerk en sy sosiale roeping (RES 1979), word gestel dat lidkerke van die liggaam wyd uiteenlopende menings oor die genoemde saak nahou. Hierdie standpunte van lidkerke wissel vanaf ' $n$ totale distansiëring van politieke betrokkenheid aan die een kant, tot by die visie aan die ander kant dat die kerk saam met ander instellings ' $n$ deelgenoot is tot politieke verandering (RES 1979: 5).

'n Kort bespreking van standpunte binne hierdie wye spektrum, aan die hand van dié verslag, kan vir die doel van die studie verhelderend wees (RES 1979: 6-11).

\subsection{Die anabaptisties-separatistiese visie}

Volgens hierdie siening staan die gelowige voor 'n radikale keuse: Christus en sy kerk teenoor die wêreld en sy gemeenskap. Geloof beteken ' $n$ keuse vir Christus en daarom wêreldvreemdheid en -vyandigheid. Die gevolge van hierdie siening is 'n reduksie van die geloof wat lei tot isolasie. 'What hath Jerusalem to do with Athens? Clearly the answer is: Nothing!' (RES 1979: 6).

Gelowiges wat hierdie standpunt huldig, weier om betrokke te raak in sosio-politiese aangeleenthede. Onderliggend hieraan is ' $n$ dualistiese polarisering tussen geestelike en wêreldlike sake.

Die verslag identifiseer die beskouing van die anabaptiste met 'n separatisme wat lei tot isolasie. Tog lê daar ook in die anabaptisme reeds iets sluimerend van die teologie van die revolusie. Dit is naamlik die idee dat die wêreld met geweld vir God se koninkryk oorwin moet word. 'Die Wederdopers wou met hulle prediking en optrede die hele bestaande orde omverwerp, om dan, volgens hulle insigte, die Koninkryk van God op aarde te vestig. Die Wederdopers het juis met hierdie fanatieke propaganda hulleself in groot ellendes gedompel. In Duitsland het die prediking van die Zwickause "profete" die kleinboere, wat in groot sosiale nood gelewe het, tot 'n algemene opstand aangedryf' (Pont 1970: 100). Alhoewel vanuit totaal verskillende beweegredes, het die anabaptisme en die teologie van die revolusie dus iets in gemeen.

\subsection{Die liberale social gospel-visie}

Hier het ons te doen met 'n 'both/and position' (RES 1979: 6) wat die skeiding tussen kerk en wêreld wil laat vervaag. Dit is ' $n$ visie wat gebaseer is op die universele broederskap van alle mense. 'n Optimis- 
tiese antropologie, gebaseer op die inherente goeie potensiaal van die mens, verwater die radikale sondigheid van die mens en sy afhanklikheid van eksterne verlossing. Kerk en gemeenskap is wedersyds betrokke op dieselfde historiese bestemming. 'Therefore the church must build bridges to society. Society needs social reform and rehabilitation, not spiritual renewal and reformation .... For Christ is the Perfector of the noblest impulses present in everyday society, and Christianity is the fulfillment of society's highest aspirations. This view is basically a kind of Christianized humanism' (RES 1979: 7). Die taak van die kerk is nie om mense individueel en gemeenskaplik tot bekering te roep nie, maar om programme tot sosiale hervorming te loods. Volgens genoemde verslag lei hierdie visie dikwels tot ' $n$ burgerlike godsdiens of 'n geënkultureerde Christendom waarin die kerk slegs sy seën uitspreek oor bestaande sosio-politieke sisteme.

\subsection{Die Rooms-Katolieke visie}

Hierdie standpunt toon ooreenkoms met dié genoem in afdeling 2.2, omdat dit ook ' $n$ beide/en posisie verteenwoordig. Dit vertoon egter tegelykertyd uiteenlopende verskille. Hierdie siening word gestruktureer volgens ' $n$ hoër-laer dualisme. Die sosiale lewensfasette behoort tot 'n laer sekulêre orde wat op sigself goed is, maar die kerk behoort tot'n hoër geestelike orde wat baie beter is. Gelowiges word geroep om in beide ordes betrokke te wees alhoewel die hoër orde van die kerk van meer waarde is. Vanuit hierdie digotomie is die geestelike van meer belang as die liggaamlik-sterflike. Die verskillende sfere van menslike aktiwiteit kan alleen gekersten word as dit te staan kom onder die genade en seën wat die kerk oor hulle uitstort.

\subsection{Die Lutheraanse visie}

'n Andersoortige beide/en visie word hier gemanifesteer, naamlik die twee-ryke of twee-werklikhede teorie. Die twee-ryke van kerk en wêreld eksisteer in 'n dialektiese wisselwerking. Christene ervaar die paradoksale suigkrag van albei werklikhede. Die kerk ontwyk nie die wêreld volgens die separatistiese model nie, maar akkommodeer ook nie die wêreldlike gemeenskap soos in die liberale model nie. Dit beteken ook nie ' $n$ sintese tussen kerk en gemeenskap soos in die Rooms-Katolieke visie nie. Christus is Heer en Koning van beide ryke, maar regeer elkeen op 'n eiesoortige wyse, naamlik deur middel van altaar en troon (RES 1979: 9). Die kerk sorg vir mense se geestelike behoeftes en die staat sorg vir die sekulêre aspekte. 
Hieruit het 'n standpunt later ontwikkel wat van geloof 'n Privatsache van die individu maak. Die taak van die kerk word dan beperk tot die sfeer van die geloof. Die gevolg hiervan was dat die kerk op grond van sy stilswye op die ander lewensterreine die bestaande orde goedkeur, ongeag hoe korrup dit ook al mag wees. Die konsekwensie van hierdie visie is dat die wêreldlike sfeer feitlik outonoom geword het, sonder inmenging van die kerk.

\subsection{Die Calvinistiese visie}

Die reformatore het weggebreek van die modelle van of/of asook beide/en. Die Calvinistiese perspektief poog om 'n totaal-eenheidsvisie van die hele lewenspektrum, sonder 'n digotomie van heilig/sekulêr, hoër/laer daar te stel. Geloof behels die ganse lewe in 'n voortgaande proses van gehoorsaamheid aan die Woord op elke lewensterrein. 'All creation fell under sin, but all of it has come again under the redeeming work of Christ. Christ is Lord of all, society as well as the church, and summons his disciples to Kingdom's service in all life's callings' (RES 1979: 10). Persoonlike versoening lei die mens tot gemeenskaplike betrokkenheid in die hervorming van die gemeenskap. 'In this way the church can be a blessing to our fellowmen. It takes its place within the kingdom as a recruitment station, a mobilization center, a training ground to equip God's people for Kingdom service in every sector of society' (RES 1979: 10).

\subsection{Die evangelical-visie}

Hier het ons te doen met 'n losse kern, bestaande uit 'n mengsel van verskeie gesigspunte. Die gemeenskap is, in die algemeen gesproke, verlore onder die sonde, maar nie so volledig dat gelowiges die wêreld moet probeer ontvlug nie. Daar is nog iets goed in die wêreld, maar nie in so ' $n$ mate dat die Christen in 'n bondgenootskap met die wêreld mag leef nie. Die gemeenskap moet binnegedring word met die lig van die Woord. Die sosiale is die terrein vir persoonlike getuienis, evangelisasie en sending. Vanweë hulle ooraksentuering van die koninkryk van God as 'n toekomsgebeure het hulle nie veel erg aan die kerstening van hedendaagse strukture en gemeenskappe nie, maar die bekering van individue. Die wedergebore Christen vind skuiling in die kerk, weg van die bose invloed van die wêreld. In die meer resente tye word by die neo-evangeliese rigtings egter meer openheid gevind vir betrokkenheid by sosiale vrae en probleme. 


\subsection{Die bevrydingsvisie}

Die RES-verslag wys aan dat hier ooreenkomste aangetref word met die radikale vleuel van die 16de-eeuse reformasie. Daar is by beide sterk klem op die realisering van die koninkryksideaal hier en nou. Die boodskap van verlossing en bevryding is nie 'n vae eskatologiese hoop nie, 'but an immediate challenge which must be transformed into a present reality' (RES 1979: 11). Volgens hierdie siening word die gemeenskap ervaar as die onderdrukker van die armes en verontregtes. Die enigste weg tot bevryding is die omverwerping van hierdie strukture deur middel van radikale revolusie. Die kerk moet wegbreek van sy tradisionele rol as verdediger van die 'establishment' en help om die gees van revolusie te genereer en te inspireer. 'It can do so best by forging a strategic alliance between Christianity and Marxism, reinforcing the Gospel message by the use of socialists methods of getting things done. In this movement to liberate society the church must take a lead role, or else the revolution will happen without the church' (RES 1979: 11).

\subsection{Keuse van 'n model}

Binne die kring van ' $n$ Calvinisties-reformatoriese kerk is die keuse van 'n model eintlik reeds gemaak, soos dit ook na vore kom in sy belydenisskrifte, gegrond op riglyne vanuit die Skrif. Hierdie model word in kort weergegee in afdeling 2.5, maar vir die doel van die studie is nadere presisering noodsaaklik. Oberholzer (1985: 28) het aan die hand van die belydenisgeskrifte en die Kerkwet van die Nederduitsch Hervormde Kerk die taak van die kerk nader omskryf, soos dit die verskillende sosio-politieke terreine raak.

Hierdie verantwoordelikheid van die kerk word gerealiseer in sy optrede na binne en buite. Na buite kom die kerk sy verantwoordelikheid na deur sy amptelike getuienis teenoor die owerheid, op versoek of spontaan. Hierdie getuienis geskied ook deur sy medewerking en betrokkenheid as kerklike orgaan of deur middel van sy lidmate by die aktiwiteite in die gemeenskap. Die fokuspunt van hierdie studie lê egter meer op die terrein van die prediking. Oberholzer (1985: 21-28) toon ook duidelik die terreine aan waar die kerk in sy prediking, kategese en herderlike werk sy lidmate vermaan en onderrig om hulle verantwoordelikheid na te kom. Hierdie verkondiging na binne deur middel van prediking, pastoraat en kategese kring weer na buite uit via die lidmate van die kerk se betrokkenheid in die politieke en gemeen- 
skapslewe. Dit geskied dus volgens die model genoem in afdeling 2.5, geskoei op die lees van Efesiërs 4:11-16, naamlik dat die kerk deur sy ampte gelowiges toerus vir hulle dienswerk in die kerk en wêreld.

In die nakom van hierdie verantwoordelikheid in sy getuienis na buite en sy verkondiging na binne, kan daar maklik grensoorskryding plaasvind. Dit kan in dié sin gebeur, naamlik dat die kerk' $n$ politieke aksiegroep word of hom op sleeptou laat neem deur politieke stromings en opvattings. Hierdie gevaar word deur talle teoloë uitgewys. Velema (1977: 18) sê tereg: 'De kerk is geen politieke actiegroep. Ze moet ook niet als zodanig willen optreden. ... Prediking is bediening van het Koninkrijk der hemelen in de gemeente van Christus. De prediking heeft dus duidelijk een binnenkerklijke functie.' Runia (1985: 100) waarsku ook teen hierdie gevaar: 'Tegelijk zullen we goed moeten beseffen waar onze grenzen liggen. Het is zeker niet de taak van de predikant om allerlei concrete politieke oplossingen aan te bevelen. Die behoren niet tot de competentie van de kerk as geheel en ook niet tot de competentie van de individuele predikant.' Van Wyk (1980: 89) maan die kerk ook tot versigtigheid om hom nie te identifiseer met politieke en ideologiese sisteme, of hom te assosieer met politieke partye nie. Oberholzer (1985: 16) wys ook op die groot versigtigheid en deernis waarmee die kerk hierdie taak moet uitvoer: 'Die hermeneutiese taak lê by die vertolking van die evangelie en by die vertolking van geval en omstandigheid. Goed en kwaad, reg en onreg is nie staties nie en kan nie deur reëls omskryf word nie. Voorkeur aan een owerheidstruktuur bo 'n ander bly daarom steeds relatief en kan maklik die weg open vir ander beweeggronde as die evangelie.'

Alhoewel dit dus duidelik blyk dat daar binne gereformeerde kring aanvaar word dat die kerk in sy verkondiging na binne en getuienis na buite 'n verantwoordelikheid ten opsigte van sosio-politieke aangeleenthede het, geskied dit nie by wyse van politieke aksieprogramme of politieke prediking nie. Die prediking as verkondiging van die Woord van God het wel ook in sy konkrete toepassing in die situasie hier en nou politieke konsekwensies, maar dit is geensins 'politieke prediking' nie. Prediking wat die lewe van die gelowige belig, is prediking toegepas op politieke aspekte, maar behoort nie polities-geinspireerde prediking te wees nie. 'In die term politieke prediking bepaalt politiek het wezen van de prediking' (Velema 1972: 27). Die Woord van God lê beslag op die mens in al sy lewensuitinge, daarom ook op sosiaal-politieke gebied. Die politieke terrein is dus maar een van vele terreine van die lewe waarop die Woord betrekking het. Daar kan en 
mag dus nooit in die prediking van die kerk 'n krampagtige strewe wees om aan elke denkbare teks 'n politieke kleur te gee of na 'n politieke toepassingsmoontlikheid te soek nie. Hierdie krampagtigheid spruit uit ' $n$ mening dat prediking alleen dan relevant is, indien dit ingaan op sosio-politiese vraagstukke. Ten grondslag hiervan lê die opvatting dat die Woord op sigself geen aktualiteit sou hê as dit nie deur ons toespitsing op 'n bepaalde politieke praxis aktueel gemaak word nie.

Jonker (1973: 43) beklemtoon die feit dat die Woord van God in sy wese aktueel is, ons hoef dit nie aktueel te makk nie. Dit is aktualistiese prediking wat die mislukking is van aktuele prediking. Hierdie aktuele Woord van God moet slegs deur die konkrete gerigtheid op en toepassing in die hede die mens in sy sistuasie aanspreek, ook op die sosiopolitiese terrein.

As ons dus aanvaar dat die kerk in sy prediking onder andere ook aandag sal gee aan die sosio-politiese fasette van sy tyd, bly dit nog steeds, homileties gesien, 'n vraag op welke wyse hy dit in sy prediking sal doen sonder om hom vas te loop in 'n mynveld van gevare wat op hierdie terrein dreig. Vanuit homiletiese gesigspunt is dit 'n hermeneutiese probleem wat ontrafel moet word, alvorens ons sekere riglyne kan stel.

\section{HERMENEUTIESE PROBLEMATIEK}

Die hermeneutiese probleem word hier gesien in die omvattende definisie, naamlik dat dit gaan om die vraag na die verstaan van die teks in sy literêre en historiese konteks, maar ook oor die vraag na die verstaan van die mens in sy huidige konteks en die probleem van die oortolking en vertolking van die een situasie na die ander sodat dit tot dieselfde verstaan van die boodskap sal lei (Pieterse 1972: 110-117). In hierdie hermeneutiese proses as verstaansgebeure kan baie ontsporings en steurings plaasvind. Hierdie proses speel hom af in ' $n$ dialektiese wisselwerking tussen drie pole, naamlik: teks, prediker en gemeente. As 'n steuring in hierdie gebeure plaasvind, kan dieselfde oorspronklike teks totaal verskillend verstaan word, afhangende van die prediker en die gemeentesituasie.

\subsection{Hermeneutiese versteurings}

Indien 'n ondersoek gedoen word na preke oor politieke aspekte blyk dit duidelik hoe maklik ' $n$ hermeneutiese versteuring intree. Hierdie 
steurnisse manifesteer in die prediking duideliker op die terrein van politieke aspekte, omdat sterk eie politieke oortuigings van die prediker die normale gang van die hermeneutiese proses maklik beïnvloed. In 'n studie van Cilliers (1982) oor 'n preekanalitiese model, word preke van Allan Boesak, AP Treurnicht en G von Rad onder die soeklig geplaas. Hy kom tot die gevolgtrekking: 'Terwyl Von Rad se waarneming deur die kommentare bepaal word, word die van die Suid-Afrikaanse predikers deur die Suid-Afrikaanse situasie, die politiek bepaal. Beide Boesak en Treurnicht neem die waarheid selektief waar, beide poog om God vir die eie saak op te eis; by beide vind waarneming deur die filter van eie interesse plaas' (Cilliers 1982: 175). 'Terwyl Treurnicht die ekklesia aan die volk prysgee, verkondig Boesak 'n ekklesia waarin Christus blykbaar nie meer teenwoordig is nie' (Cilliers 1982: 192).

Die politieke oortuiging van die prediker en sy vertolking van die situasie van sy tyd versteur dus die hermeneutiese gebeure in so 'n mate dat feitlik totaal teenstrydige boodskappe uiteindelik gepreek word.

In 'n ondersoek van Botes (1983) aan die hand van twee preke van Allan Boesak kom hy tot die gevolgtrekking dat die teks uit sy Umwelt losgemaak is en dat die historiese konteks glad nie ter sake is by die prediking nie (Botes 1983: 31). Hy maak ook die verdere stelling: 'Prediking binne die Swart Teologie gaan uit van 'n bepaalde hermeneutiese invalshoek, naamlik die gedagte van bevryding. Hierdie bevrydingsgedagte is so oorheersend in die teologie, dat dit die boodskap van die Skrif verskraal en verdraai' (Botes 1983: 34).

Venter (1983) identifiseer dat in die sosio-politieke relativering van die Bybel ' $n$ aantal faktore van deurslaggewende belang is in die versteuring van die korrekte hermeneutiese gebeure. Dit is opvallend dat 'n groter gewig aan die Ou-Testament toegeken word, omdat dit waarskynlik as 'n meer 'politieke dokument' geag word as die Nuwe Testament wat meer neutraal is. Daar is dus die gevaar van 'n selektiewe ooraksentuering van sekere dele van die Skrif ten koste van 'n gebalanseerde geheel. Venter (1983: 110) wys ook op die probleem van teks en konteks. Die ondersoeker het reeds bepaalde vooronderstellings wat in die teks ingelees word, sonder inagneming van die historiese konteks waarbinne die teks figureer. Hieruit voortvloeiend is die knelpunt van analogie: 'Dit word as vanselfsprekend aanvaar dat daar analogie bestaan tussen kontemporêre sosio-politieke stelsels en die stelsels wat in die Ou Testament ter sprake kom' (Venter 1983: 111). Hy toon oortui- 
gend aan dat die sosio-kulturele situasies van die Ou Testament en vandag so uiteenlopend verskil dat alhoewel daar oënskynlike ooreenkomste is, daar tog diepliggende verskille is wat die verstaan, oortolk en vertolk bemoeilik.

Vanaf die kant van die hoorder kan daar ook as gevolg van 'n te skerp polities-geïnspireerde prediking struikelblokke ontstaan wat die hermeneutiese gebeure belemmer. Die prediking is in sy wese ' $n$ dialogiese gebeure, maar in sy vorm monologies. 'A political sermon is normally understood to be a sermon in which the preacher expressly takes a certain stand on a controversial matter. Listeners generally do not appreciate this' (Van der Geest 1981: 103). Vanuit 'n psigologiese oogpunt stel Van der Geest dat party-politiese uitsprake berus op persoonlike keuses en interpretasie van die huidige situasie deur die prediker - dit lei tot aggressie by die hoorders. Sulke uitsprake hoort volgens hom tuis by 'n gespreksgeleentheid waar in ' $n$ dialoog oor die saak gedebatteer kan word. Vanweë die monologiese vorm van die prediking is die hoorder tot swye gedoem en kan dus nie sy persoonlike argumente ter oorweging aanbied nie. Dit lei tot 'n gevoel van aggressie en frustrasie wat die kommunikasie tussen sender en ontvanger heeltemal kan blokkeer.

\subsection{Gevolgtrekkings}

Die vernaamste steurnisse in die hermeneutiese gebeure, veral by prediking met 'n politieke gerigtheid, kan dus soos volg saamgevat word:

- 'n Reduksie van Bybelse stof tot gedeeltes met moontlike politieke inhoude.

- 'n Polities-geïnspireerde voorverstaan van die teks, los van sy konteks.

- 'n Reglynig oorvereenvoudigde analogie tussen die situasie van die teks en die kontemporêre situasie.

- 'n Verskraling van verantwoorde eksegese van die teks binne sy literêre en historiese konteks.

- 'n Interpretasie van die huidige situasie op grond van ongekontroleerde eie voor- of afkeure van die prediker.

- 'n Steuring in die kommunikasiegebeure vanweë die monoloogvorm van die prediking wat nie ruimte bied vir gesprekvoering nie. 


\section{MOONTLIKE HOMILETIESE RIGLYNE}

Die hermeneutiese proses is ' $n$ gekompliseerde gebeure wat alreeds begin by die keuse wat die prediker maak ten opsigte van stof vir sy prediking. Hierdie keuse berus reeds op 'n sekere voorverstaan van die teks, gebore uit sy meditasie oor die teks. 'n Bepaalde verstaansgebeure het sigself dus reeds voltrek voordat die prediker as wetenskaplike teoloog met die teks begin omgaan. Die hermeneutiese proses loop deur sy eksegetiese dekodering van die teks tot by sy eie verstaan van die boodskap van die teks. Hierdie boodskap van die teks wat met hom gekommunikeer het, moet nou egter ingetolk en vertolk word in die situasie van die gemeente hier en nou, ook genoem die enkodering van die boodskap in ' $n$ nuwe verstaanshorison. Hierdie enkodering van die boodskap in sy nuwe verstaanshorison word weer op sy beurt grotendeels bepaal deur die prediker se eie verstaan van die situasie van die gemeente. Hierdie twee fasette, naamlik die prediker se verstaan van die teks en sy verstaan van die situasie van die gemeente, is egter nie twee fases van die hermeneutiese proses wat van mekaar in waterdigte kompartemenete geskei kan word nie. Van die begin van die hermeneutiese proses is albei hierdie fasette in 'n dialektiese wisselwerking met mekaar betrokke: in die persoon van die prediker, deur middel van sy meditasie oor teks en situasie. Tereg sê Van Aarde (1984: 127): 'Die weg van die teks na die preek is daarom die pad wat die hermeneut as homileet moet gaan. Daar is nie ' $n$ plek op hierdie pad waar die een soos ' $n$ aflosatleet by die ander oorneem nie. Die homileet is met ander woorde nie iemand wat maar net van die resultate van die eksegese gebruik maak nie.'

Juis omdat die hermeneutiese proses ' $n$ geïntegreerde, gekompliseerde gebeure is wat nie geïsoleerd gebeur nie, maar binne die persoon van die prediker in ' $n$ dialektiese proses afspeel, is dit so moeilik om te onderskei tussen wetenskaplike eksegese en persoonlike interpretasies. Tog sal ons moet probeer om in die prediking bewus te wees van die gevaar van ' $n$ ongekontroleerde vermenging van wetenskaplike verstaan en persoonlike voorverstaan. ' $n$ Verdere probleem in die hermeneutiese proses wat hier uitgewys moet word, is die denkfout dat die hermeneutiese proses voltrek is op die oomblik wanneer die preek gemaak is. Hierdie leemte kom na vore in die homiletiese besinning oor hierdie saak wat gewoonlik omskryf word as: 'Die weg van die teks na die preek' (Van Aarde 1984: 123). Die hermeneutiese proses is nie met die maak van die preek voltrek nie; ook nie met die lewer van die 
preek nie; ook nie met die gemeente se luister en verstaan van die preek nie - nee, die proses loop nog verder deur. 'From a message perspective, the sermon begins at 11:35 a m and ends at 11:55 a m. From a process perspective, it begins with the study of a text or with a provocative pastoral call or with the formulation of a sermon outline. The sermon ends when the last word is spoken from the pulpit; or when the last parishioner, making a comment about the sermon, leaves the place of worship; or when reflection on a given sermon ceases' (Chartier 1981: 15). Die hermeneutiese proses loop dus deur tot daar waar die gemeentelid in sy lewe van elke dag die boodskap van die teks in sy handelinge reflekteer. In die lig van hierdie omskrywing van die proses sou ons dus veeleer moet praat van die gebeure vanaf die teks tot by die lewe van die gemeente, gevorm deur hulle verstaan van die teks.

Vanuit hierdie omvattende verstaan van die hermeneutiese proses as geïntegreerde gebeure, wil ons poog om enkele gevaarpunte en riglyne uit te wys wat by alle prediking, maar veral prediking met ' $n$ politieke gerigtheid, in ag geneem moet word. Sodoende kan versteurings in die verstaansgebeure so ver as moontlik uitgeskakel word. Alhoewel dit'n geïntegreerde proses is, sal ons tog ter wille van sistematiese besinning die proses moet probeer lostorring en stapsgewys sekere sake identifiseer.

\subsection{Die keuse van preekstof}

Een van die groot probleme rondom politieke en sosiale vraagstukke in die prediking lê rondom die keuse van die preekstof. Venter (1983) het reeds gewys op die neiging om in dié tipe prediking meer gebruik te maak van stof uit die Ou Testament, omdat dit 'n meer politieke geladenheid bevat. ' $n$ Prediker met sterk politieke oortuigings en belangstelling sal dus uit die aard van die saak geneig wees om te soek na dié gedeeltes in die Skrif waar oënskynlik politieke uitsprake gemaak word. Vanuit dié ingesteldheid van die prediker kan dus feitlik elke preek 'n polities-gerigte preek word. Die probleem raak nog meer intens wanneer in ag geneem word dat die prediker sy preekstof so kan selekteer dat net één bepaalde politieke aksent vanuit die Bybelse stof uitgehaal word. Binne die Suid-Afrikaanse situasie kan dit in praktyk beteken dat die een prediker, vanuit sy politieke siening van verandering van strukture en bevryding van onderdruktes, hom in sy tekskeuse toespits op profetiese literatuur soos Amos en Jeremia of die Eksodusgebeure. ' $n$ Volgende prediker kan vanuit sy politieke siening 
van behoud van bestaande strukture hom in sy keuse toespits op Skrifgedeeltes wat onderdanigheid aan die owerheid eis. Die een kan soek na Bybelse stof wat die gedagte van eenheid oor alle grense heen beklemtoon, die ander soek weer na Bybelse stof wat die verskeidenheid beklemtoon. Hierdie wyse van tekskeuse word dus bepaal deur die eie politieke siening van die prediker en lei noodwendig tot 'n eensydige politieke aksent in sy prediking. En in albei gevalle loop dit uit op 'n voortdurende politieke betrokkenheid in die prediking. Die balans kan ook versteur word na die ander kant as 'n prediker, wat weinig persoonlike belangstelling in die politiek het, eenvoudig dié Skrifgedeeltes wat wel duidelike politieke implikasies het, vermy.

In die homiletiek word die probleem in verband met die keuse van preekstof na twee kante gepolariseer. Die vryheid van die prediker word deur die voorgeskrewe perikope aan die hand van die kerklike jaar aan bande gelê. Barth (1966: 76), byvoorbeeld, is 'n sterk voorstander van prediking oor voorgeskrewe perikope of serieprediking. Hier word dus geen of weinig ruimte gelaat vir die vrye keuse van ' $n$ teks deur die prediker. Die polarisasie na die ander kant beteken dat geen voorskrifte gegee word nie, maar dat die prediker absolute vryheid in die keuse van sy preekstof het. Beide polarisasies kan vir die prediking skadelik wees. Voorskriftelike prediking hou nie rekening met die wisselwerking tussen preek en situasie nie. Dit kan daartoe lei dat die prediking by die aktuele vraagstukke van die dag onaangeraak verbygaan. Die gevare van 'n absolute vrye keuse is reeds aangedui.

'n Gebalanseerde metode van tekskeuse wat ruimte laat vir die vryheid van die prediker, maar ook sorg vir ' $n$ ewewigtige verkondiging, lyk noodsaaklik. Dit sal neerkom op 'n geïntegreerde model van tekskeuse wat die positiewe aspekte van elke metode integreer. Die volgende kan in die verband oorweeg word.

- Die kerklike jaar bepaal dat al die belangrikste heilsgebeure en feesgeleenthede jaarliks aan die orde kom.

- Die Sondae wat nie deur die kerklike jaar voorgeskryf word nie, moet op 'n sistematies-beplande wyse gevul word deur gebruik te maak van verskillende metodes.

- Boekprediking of serieprediking bevry die prediker van eensydige seleksie en laat die teks in sy konteks van die boek beter tot sy reg kom.

- Kategismusprediking sorg ook vir die nodige balans om alle fasette van die geloof te belig. 
- Vrye keuse van preekstof kan by bogenoemde geïntegreer word wanneer die prediker vanuit sy pastorale betrokkenheid ' $n$ bepaalde vraagstuk uitwys wat in belang van 'n groot deel van die gemeente is.

\subsection{Eksegese en voorverstaan van die teks}

Venter (1983) het reeds gewys op die gevare van voorverstaan en vooronderstellings wat bewustelik of onbewustelik op die ondersoekproses inwerk. 'Die persoon het reeds bepaalde sosio-politieke vraagstukke geïdentifiseer en ook geformuleer ... hy kan uit die verskillende moontlikhede wat die teks inhou, een betekenis uitkies wat sy eie standpunt ondersteun en dit verabsoluteer .... Die ondersoeker se standpunt word beaam met die vermeende betekenis van die teks wat hy ondersoek' (Venter 1983: 111).

Buss (1979: 143) probeer drie riglyne neerlê wanneer die eksegeet met polities-gelaagde tekste werk: 'First, the political import cf a text must be identified and explicated according to the norms of sound scholarly exegesis. Second, the text must be related to other scriptural teaching. Third, some theory and procedure must be provided for applying specific texts to contemporary political issues.' Ten opsigte van die norme van genoemde eksegese beklemtoon hy dan die belangrikheid dat die teks in sy historiese konteks verstaan moet word.

Die prediker kan nooit sonder vooronderstellings wees nie. Hy sal nogtans deur verantwoorde, akademiese eksegese eers die teks self met behulp van alle relevante eksegetiese metodes tot spreke moet bring, soos wat die teks self in sy historiese konteks sowel as in sy makro- en mikrokonteks sy eie boodskap genereer. Dit sal beteken dat die prediker die openheid moet hê om sy eie meditasie oor en vooronderstellings van die teks deur sy eksegetiese resultate te laat korrigeer. Dit kan soms vir die prediker ' $n$ pynlike proses wees, omdat vermeende betekenisse en argumente wat hy rondom die teks gebou het, as vals ontmasker word. Hier kom iets van die integriteit en verantwoordelikheid van die persoon van die prediker op die spel. Die beslissende vraag is hier of hy bereid is om eerlik in die gebed en geloof hom onvoorwaardelik oop te stel vir die appèl van die Woord van God.

Verantwoordelike, akademiese eksegese en gelowige openheid om jou eie vooronderstellings te laat korrigeer, sal daartoe lei dat die werklike kerugma van die teks ontbloot sal word. Hierdie kerugma sal dan oorgedra en vertolk moet word binne die eietydse situasie van die gemeente. 


\subsection{Teologiese inkleding van die kerugma}

Hier moet dit duidelik gestel word dat prediking meer is as blote eksegese van een bepaalde teks. Dit gaan in die prediking nie net om die uitleg van 'n bepaalde teks nie, maar om die verkondiging van die Woord van God, vanuit die vertrekpunt van 'n bepaalde teks. Dit beteken dat die teks in sy oordrag aan die gemeente nie slegs as ' $n$ losstaande geïsoleerde teks gesien word nie, maar dat die kerugma van die teks ook in verband staan tot die wyer eenheid van die kerugma van die Skrif as geheel. Prediking as verkondiging van die Woord van God vra dus dat die kerugma van één onderdeel van die Skrif gesien sal moet word teen die breër agtergrond van die Skrifboodskap. In die prediking vind daar dus noodwendig 'n stuk teologiese inkleding plaas. Dit kom ook in die tweede voorwaarde na vore wat Buss (1979: 143) stel in verband met die prediking van polities-gelaagde tekste, naamlik die verband van die besondere teks met ander uitsprake van die Skrif. Hierin kan die dogmatiek vir die prediker tot groot hulp wees. 'Behalwe die hulp wat die dogmatiek bied in die verstaan van 'n spesifieke teks se boodskap in die lig van die sentrale boodskap van die hele Skrif, moet die dogmatiek by uitstek die homiletiek bystaan in die onbevreesde vertaling van die boodskap vir die hede' (Pieterse 1972: 120). 'The claim is valid only if the text is indeed representative of the fundamental lines of scriptural thought on the subject and consonant with other important teachings' (Buss 1979: 144). Barth (1966: 49) sê in hierdie verband die volgende: 'Bekenntnis ist Verantwortung, Antwortgeben auf das, was gesagt ist. Die Predigt kann nicht anders geschehen als nach der Norm der in der Kirche geltenden Bekenntnisse. Jede Predigt kann nichts anderes sein als ein Akt der Verantwortung gegen den Ruf, eng angeschlossen an das Symbol.'

\subsection{Konkretisering van die kerugma in die kontemporêre situasie}

Die grootste probleem in verband met die politieke en sosiale aspekte in die prediking sentreer rondom die vraag op watter wyse die kerugma van die teks in die huidige situasie gekonkretiseer moet word? Die probleem kom na vore in die prediking van twee tipe tekste. Eerstens is daar die teks wat reeds in sy historiese konteks 'n politieke gerigtheid het, veral gedeeltes in die Ou Testament wat gerig is op ' $n$ bepaalde politieke situasie van die tyd. Venter (1983: 111) het reeds gewys op die probleem van analogie. Dit kan nie as vanselfsprekend aanvaar word dat daar 'n reglynige analogie bestaan tussen die sosio- 
politieke stelsels van die Ou Testament en dié van vandag nie. 'Histories gesien, word ' $n$ moderne stelsel met 'n klassieke struktuur gelykgestel en filosofies gesien, word die antieke stelsel preskriptief vir die huidige stelsel. Hermeneuties gesien, beteken dit dat die gesag van die Skrif opereer in die sosiale strukture wat dit beskryf. ' $n$ Mens kan na die Bybel gaan met die verwagting om daarin 'n preskriptiewe model vir ons sosio-politieke strukture te vind' (Venter 1983: 112). Al sou die teks dus in sy historiese konteks sekere politieke uitsprake maak, kan dit nie so reglynig oorgeplaas word op die huidige situasie nie. Die betekenis van die teks in sy historiese konteks sal eers nagegaan moet word. Daaruit sal dit duidelik word of dit as ' $n$ tydlose beginsel kan geld en of dit slegs in die historiese situasie 'n bepaalde betekenis gedra het. Indien daaruit wel 'n teologiese beginsel gehaal kan word, sal die beginsel eers in die huidige situasie gekonkretiseer kan word as hierdie situasie grondig ontleed en geïnterpreteer is.

Alhoewel daar dus reeds in sekere tekste 'n politieke gerigtheid binne historiese konteks is, is daar in die tweede plek egter ook tekste wat binne sy literêr-historiese konteks polities neutraal funksioneer. So is byvoorbeeld die groot gebod van die naasteliefde binne sy konteks nie 'n polities-gerigte uitspraak nie. Tog is daar in die gebod van die naasteliefde, indien dit toegepas word binne sosio-politieke verband, duidelike politieke konsekwensies. Hier word egter in die teks geen riglyne gegee vir sosio-politieke aangeleenthede nie, en sal die prediker dus, indien hy dit wil toepas op sosio-politieke terrein, self die ryglyne moet neerlê.

Om hierdie probleem van die konkretisering en vertolking van die kerugma in die kontemporêre situasie te orden, is verskeie riglyne deur teoloë voorgestel. Die mees algemene is die volgende:

- Slegs algemene teologiese beginsels moet gestel word en die beslissing in die praktyk moet oorgelaat word aan die individuele gewete (Dijk s a: 35);

- die meeste is dit eens dat geen party-politieke uitsprake op die preekstoel gebring mag word nie (Runia 1985: 92);

- die saak moet van genoegsame belang wees (Runia 1985: 93);

- dit moet 'n saak wees wat die volk of owerheid nie langs ander kanale kan bereik nie (Runia 1985: 93);

- die kerk moet dié uitsprake in 'Gods Naam' kan maak (Runia 1985: 93);

- die onderwerp moet direk iets te make hê met die lewenspraktyk van die gemeente (Runia 1985: 93); 
- Die kerk sal in sy prediking slegs onthullend en ontmaskerend die smaad en verkeerde aan die lig moet bring, sonder om direkte voorskrifte te gee (Velema 1977: 11);

- 'als de landelyke kerk hem is voorgegaan in de toepassingen die hij geeft, als ook de eigen kerkeraad er achterstaat en vooral ook als het zijn eigen diepe heilige overtuiging is' (Runia 1985: 94).

Uit hierdie riglyne is dit duidelik dat teoloë uiters versigtig is vir die konsekwensie van die konkretisering van die kerugma op politieke terrein. Hierdie riglyne is vaag en onbeduidend en bied geen oplossing vir die probleem nie.

Waar lê byvoorbeeld die grens tussen algemene beginsels en partypolitieke uitsprake? In sekere situasies het algemene beginsels in sigself party-politieke konsekwensies sonder dat die prediker die lyn deurtrek. Moet die kerk slegs negatief onthul en kritiseer, of het hy ook 'n taak om positief leiding te gee? Kan die persoonlike oortuiging van die prediker, al is dit ook hoe eerlik en goed bedoeld, ooit tot norm vir die gemeente verhef word? Sekere van hierdie riglyne wat genoem is, kan wel gebruik word, maar sal nader omskryf moet word.

Die brandende vraagstuk van die verhouding tussen teorie en praktyk is ' $n$ vraag waaroor beoefenaars van die Praktiese Teologie vir baie jare indringend besin het. Finale uitsprake kan nie so maklik gebied word nie. Radikalisering na een van beide pole hou gevaar in. In die artikel van Otto (1975: 9-31), 'Praktische Theologie als kritische Theorie religiös vermittelter Praxis in der Gesellschaft', blyk duidelik die gevaar dat die praxis uiteindelik soveel invloed kan uitoefen dat dit voorskriftelik word vir die teologies-gevormde teorie. In die tradisionele besinning oor die Praktiese Teologie in die algemeen, en die Homiletiek in die besonder, kan baie eksponente gevind word van teoloë wat 'n pragtige teologiese teorie oor byvoorbeeld die prediking ontwerp, maar nalaat om die praxis waarbinne die prediking moet inspreek, enigsins te verdiskonteer (Dijk 1955). Pieterse (1985) raak ook die probleem van die verhouding tussen teorie en praktyk aan in sy besinning oor die prediking. Hy kies vir 'n kritiese teorie wat bestaan uit 'n kritiese interaksie tussen teorie en praktyk, maar waarin geen voorrang aan die teorie toegeken word nie (Pieterse 1985: 4). Die kritiese wisselwerking is onontbeerlik, maar teologies wil ons tog kies vir 'n normatiewe voorrang wat aan die teologiese teorie toegeken moet word. Die belangrikste saak wat hy reg beklemtoon, is dat die 
Praktiese Teologie alleen sinvol die praxis kan benader, indien hy eers op grond van empiries-analitiese metodes die praxis ondersoek het.

Soos reeds aangetoon, is die grootste probleem rondom politieke en sosiale vraagstukke in die prediking juis die interpretasie van die werklikheid wat op persoonlike sienings berus. Die prediker kan dus veral in dié verband nie volstaan met sy eie siening en verstaan van sosio-politieke vraagstukke nie, maar sal hom moet laat lei deur wetenskaplike resultate gebaseer op empiries-analitiese ondersoeke. Deur hierdie stelling is die probleem egter nog steeds nie opgeklaar nie, want die rou gegewens wat verkry word vanuit wetenskaplike ondersoeke, moet ook weer op hulle beurt teologies geïnterpreteer en geëvalueer word. Ook hierdie fase kan die prediker nie geïsoleerd doen vanuit sy eie voor- of afkeure nie. Dit is daarom ook te verstane dat teoloë (bv Runia 1985: 94) pleit dat uitsprake van politieke aard ook eers deur die kerk as geheel bespreek moet word.

Dit lyk dus noodsaaklik dat daar op deurlopende basis deur die kerk as geheel ondersoek gedoen moet word na sosio-politieke vraagstukke. Hierdie bevindings sal sover moontlik deur die kerk geïnterpreteer en geëvalueer moet word om te dien as riglyne vir die prediking van die kerk. Dit is die enigste verantwoordelike wyse waarop die kerk kan toesien dat ook in sy prediking daar op gebalanseerde wyse ingegaan kan word op sosiale en politieke vraagstukke. Indien die kerk in sy wyer verband nie hierdie verantwoordelikheid aanvaar nie, sal dit daartoe lei dat prediking oor politieke aspekte uitgelewer sal word aan die persoonlike oortuiging van die prediker met nadelige gevolge vir die lewe van die plaaslike gemeente.

In die Hervormde Kerk is die eerste treë in die rigting gewaag met sy projek 'Kerk en Wêreld 2000'. Hierdie rapport het ook as studieverslag voor die Algemene Kerkvergadering van Mei 1986 gedien. Hierin het die kerk hom uitgespreek oor sekere sake van sosio-politieke aard. Dit is uitsprake wat op sy beurt weer kan dien as bakens vir die prediking.

Samevattend kan as riglyne vir die konkretisering van die kerugma binne sosio-politieke verband die volgende gestel word:

- Tekste met ' $n$ inherente politieke strekking moet binne hulle konteks verstaan word en die prediker moet versigtig wees vir direkte analogie tussen die historiese situasie en vandag;

- tekste wat inherent polities neutraal is, het soms wel in hulle konkretiseringsmoontlikhede politieke implikasies, maar dit sal alleenlik gedoen kan word op 'n wetenskaplik-verantwoorde ontleding van die werklikheid van vandag; 
- die kerk as geheel sal voortdurend die werklikheid empiries-analities moet ondersoek en sy resultate teologies evalueer en interpreteer om as riglyne vir die prediking te dien;

- selfs op grond van hierdie riglyne van die kerk sal die prediker party-politieke propaganda in sy prediking ten alle koste moet vermy ter wille van die welwees van die gemeente;

- polities-gelaaide begripsmateriaal is in die prediking onvanpas, omdat dit ruimte bied vir ongeregverdigde afleidings wat aggressiewe emosies wek;

- sosio-politieke uitsprake in die prediking moet altyd geskied in terme van tydelikheid in ' $n$ bepaalde situasie. Dit moet nooit tot ewigheidswaarde vir die lewe van die gemeente verhef word nie.

\section{5 'Feedback' as komponent van 'n gebalanseerde kommunikasiegebeure}

Volgens kommunikasiemodelle is ' $n$ onontbeerlike element vir sinvolle kommunikasie die so genoemde 'feedback' of terugvoering (Chartier 1981: 24). Dit is hierdie element wat van kommunikasie 'n tweerigtingverkeer maak. Die beginsels van terugvoering maak dit moontlik dat die sender kan kontroleer of sy boodskap reg gedekodeer en verstaan is. Slegs dan het geslaagde kommunikasie plaasgevind.

Een van die grootste besware wat teen die prediking as monoloog ingebring word, is dat dit nie die geleentheid tot terugvoering bied nie en daarom as kommunikasiegebeure nie effektief is nie. Alhoewel die prediking 'n eiesoortige kommunikasiegebeure met sy eie inherente pneumatologiese dinamiek is, kan hierdie beswaar nie eenvoudig negeer word nie, want in sy wese wil prediking 'n dialoog bewerkstellig.

Die beginsel van terugvoering kan moeilik in die liturgiese opset geakkommodeer word. Tog pleit teoloë daarvoor dat rondom die erediens geleentheid vir terugvoering geskep sal word. Hierdie terugvoering vind reeds nie-amptelik plaas deur die pastorale verhouding tussen pastor en sy gemeente. De Klerk (1977: 92-101) bepleit dat, bo en behalwe hierdie bestaande spontane terugvoering, daar op 'n vaste basis gestruktureerde terugvoeringsgeleenthede by wyse van preekbesprekingsgeleenthede geskep sal word. Hierdie terugvoering is vir die prediker noodsaaklik om te kan vasstel of sy boodskap reg verstaan is, maar ook om te bepaal watter konkrete betekenis die boodskap, vanuit hulle verwysingsraamwerk, vir hulle inhou.

Die beginsel van terugvoering is belangrik vir die prediking in geheel. Dit is des te meer so wanneer politieke en sosiale vraagstukke aan 
die orde kom. Deur hierdie terugvoering raak die prediker bewus van die leefwêreld en vrae van sy gemeente en kan hulle saam vanuit die riglyne wat die kerk bied, na antwoorde soek. Deur middel van hierdie gesprek kan die refleksie van die preek in die lewe van die gemeente as voortgaande gesprek aan die orde kom.

Vanuit die beginsel van terugvoering as onontbeerlike komponent van die kommunikasieproses, veral ten opsigte van politieke en sosiale vraagstukke, kan die volgende as riglyne saamgevat word:

- 'n Deurlopende gespreksgeleentheid as terugvoering op die prediking moet op 'n gestruktureerde wyse geskep word.

- Die gesprekgeleentheid leer die predikant begrip vir die verwysingsraamwerk van die lidmate.

- Dit bevry die predikant van uitsprake wat bloot gebaseer is op persoonlike oortuiging.

- Dit kan dien as 'n studiegroep op gemeentelike vlak rakende politieke en sosiale vraagstukke.

\section{SLOTOPMERKINGS}

Politieke en sosiale vraagstukke bly 'n sensitiewe gebied vir die prediking. Dit moet egter nie daartoe lei dat dié sake vermy word nie, want dan maak die kerk homself en sy boodskap in sekere opsigte irrelevant vir sy tyd. Die prediker sal met bogenoemde riglyne dit ook op dié gebied met groot versigtigheid en verantwoordelikheid moet waag. So baie hang af van die persoonlikheid en ingesteldheid van die prediker: sy eie roepingsbewustheid; sy verantwoordelikheid teenoor sy Sender; sy pastorale bewoënheid teenoor sy gemeente; sy gevoeligheid vir die vrae van sy tyd; sy manier van oordrag op die kansel; sy optrede in die gemeenskap - dit alles dra by tot die klimaat waarbinne hy die Woord moet spreek. 'n Wanbalans in hierdie genoemde aspekte kan 'n goedbedoelde woord totaal anders laat oorkom by sy gemeente. Moedswilligheid, 'n gebrek aan takt en verskuilde motiewe kan van die politieke en sosiale vraagstukke in die prediking 'n kruitvat maak en dit kan onberekenbare skade aan die gemeente van die Here berokken.

Miskien is dit goed om in hierdie verband af te sluit met 'n wyse woord van Barth (1966: 68): 'Takt haben heisst wissen was jeweils im einzelnen der Gemeinde zu zagen gewagt werden darf. Wir meinen gar manches Mal, es müsse etwas gesagt sein, sogar an Hand der Bibel und es ist doch nur Übermut und mutwilliges Aufs-Spiel-Setzen des Vertrauensverhältnisses und unnötiges Ärgernis.' 


\section{Literatuurverwysings}

BARTH, K 1966. Homiletik, Wesen und Vorbereitung der Predigt. Zürich: EVZ

BOTES, MCE 1983. ' $n$ Kritiese beoordeling van prediking binne die swart teologie aan die hand van Ps 72 en Hab 2:2-4. BD-skripsie, Universiteit van Pretoria.

BUSS, MJ (ed) 1979. Encounter with the text. Philadelphia: Fortress.

CHARTIER, MR 1981. Preaching as communication: An interpersonal perspective Nashville: Abingdon.

CILLIERS, JH 1982. Soos woorde van God: Ontwerp van 'n preekanalitiese model. D Thproefskrif, Universiteit van Stellenbosch

DE KLERK, JJ 1977. Prediking. Pretoria: NG Kerkboekhandel.

DIJK, K 1955. De dienst der prediking. Kampen: Kok.

DIJK, K s a. Kerk en politiek. Franeker: Wever.

GAUM, F 1981. Die kerk en die toekoms van Suid-Afrika. Pretoria: NG Kerkboekhandel.

JONKER, H 1973. En toch preken. Nijkerk: Callenbach.

JONKER, WD 1976. Die Woord as opdrag. Pretoria: NG Kerkboekhandel.

OBERHOLZER, JP 1985. Die taak van die kerk teenoor die owerheid. HTS 42, 14-28.

OTTO, G (Hrsg) 1975. Praktisch Theologisches Handbuch. Hamburg: Fürche.

PIETERSE, HJC 1972. Skrifverstaan en prediking. Pretoria: NG Kerkboekhandel.

PIETERSE, HJC 1985. Verwoording en prediking. Pretoria: NG Kerkboekhandel.

PONT, AD 1970. 'n Oorsig van die algemene kerkgeskiedenis en geskiedenis van die Nederduitsch Heroormde Kerk van Afrika. Pretoria: HAUM.

REFORMED ECUMENICAL SYNOD 1979. The church and its social calling. Grand Rapids. RUNIA, K 1985. Prediking en politiek-sociale vragen. Theologia Reformata 28/2, 86-98.

VAN AARDE, AG 1984. Die weg van die teks na die preek: Die verkondiging van die Nuwe Testament as 'n kommunikasiegebeurtenis. HTS 40/1, 123-140.

VAN DER GEEST, H 1981. Presence in the pulpit: The impact of personality in preaching. Georgia: Knox.

VAN WYK, DJC [1980]. Die roeping van die kerk ten opsigte van die politieke situasie in Suid-Afrika vandag. HTS 37/1,83-93.

VELEMA, WH 1972. Politieke prediking. Kampen: Kok.

VELEMA, WH 1977. Kerk-politiek-prediking. Theologia Reformata 20/1, 5-24.

VENTER, PM [1983]. Sosio-politieke relativering van die Bybel. HTS 39, 110-122. 